\title{
Fund Management - An Exploratory Case Study of Several Mosques in Kelantan
}

\author{
Mohd Rushdan Yasoa, ${ }^{1}$, Mohd Safwan Ghazali ${ }^{1}$, Mohd Afifie Mohd Alwi ${ }^{1}$, Azira Hanani Ab Rahman ${ }^{1}$, Siti Salwani \\ Abdullah ${ }^{1}$, Ahmad Ridhuan Abdullah ${ }^{1}$, Mohammad Ismail ${ }^{1} \&$ Mohd Rafi Yaacob $^{1}$ \\ ${ }^{1}$ Faculty of Entrepreneurship and Business, Universiti Malaysia Kelantan, Malaysia \\ Correspondence: Mohd Rushdan Yasoa', Faculty of Entrepreneurship and Business, Universiti Malaysia Kelantan, \\ Malaysia.
}

Received: May 1, 2019

Accepted: June 1, 2019

Online Published: July 7, 2019

doi:10.5430/rwe.v10n2p53

URL: https://doi.org/10.5430/rwe.v10n2p53

\begin{abstract}
This paper attempts to identify the mosques' source of fund, distribution of fund, and parties responsible in managing the fund. This study was conducted using qualitative data through in depth interviews on three different mosques in Kelantan. The findings of this study further solidify results of previous research where it was found that the main sources of mosques' fund were from public charity contributions. The fund was also found to be utilized optimally on operations and physical development of the mosques.
\end{abstract}

Keywords: fund management, fund sources, fund distribution, efficiency, religious centre

\section{Introduction}

Majority of the mosques in Malaysia did not utilize the fund effectively and they were more inclined to park the fund in banks or any financial institutions as their saving investment only to have a minimal return. This somehow limited the mosques activities organized for the locals (Azila et.al, 2014; Rafindadi \& Kondo 2018).

Lack of funds would impact the activities of local community as well as the mosque's physical development (Jamaliah Said et.al, 2013). In the context of physical development, most of mosques would run a collection from their congregations or anyone who intended to contribute as a charity. Nowadays, more and more mosques utilize the conveniences of social media as their platform to collect funds for the purpose of physical renovation and expansion.

With regards to this study, three mosques were chosen and they were Mosque A (Machang), Mosque B (Kubang Kerian), and Mosque C (Pengkalan Chepa). These three mosques were chosen because they were located in areas that have the densest population. They were also had been generally viewed as very active in organizing religious activities and quite inclined to do business activities.

There are lacks of studies done on mosques and thus the source of reference was very limited. While most of the previous studies were more focused on fund management and its administration in general, this study examines its source and fund management intensively. Ideally, this study is significant in observing and knowing the fund management of mosques as well as its impact on local communities.

\section{Literature Review}

\subsection{Management and Administration of Mosques}

During the time of Prophet Muhammad S.A.W, mosques were not limited only for religious activities. In fact, it also played a huge part as a centre for administration, economic and finance development, social activities, judiciary, defence, education, expansion of Islam and many more (Shaik Ali Mohamed Mokhtar, 2003; Zaimche, 2002; Joni Tamkin \& Che Zarrina, 2003). Over time however, the functions of mosques seemed to be deteriorated, narrowed and limited to only as a worshipping centre and for spreading the teachings of Islam or da'wah Islamiyyah (Azila et.al, 2014). Fidlizan and Mohamad Yahya (2009) observed through their study that society nowadays perceived mosque to have very limited functions, whereby all of their other original functions are now being taken care of by other institutions such as the ministry, boards, and centres. Although mosques today do not function as administrative centre, their roles in shaping the society still exist and functioning (Mohamed Azam et.al, 2013; Promsri, 2018). 
In order to make sure the administration and management of the mosques run smoothly, two groups of the committee usually are appointed by the state's Islamic Council and Religious Department. The first group were those who were appointed and paid by the State Islamic Council such as the Imam Besar, Imam Tua, Imam/ Imam Muda, Khatib, Bilal, and Siak and they were responsible on tasks related to religious matters. While the later were the mosque's committee members that include representative from Religious Department or any other government agency, and local individuals who were appointed through nomination in general meetings subject to verification by the Council. These committee members would be voluntarily responsible in managing the fund and strategize its utilization for programs or activities planned. Therefore, most of them were not paid in performing their duties (Fidlizan et.al, 2008; Mohd Yahya et.al, 2014; Joni Tamkin, 2011 \& Maliah Sulaiman, 2008; Stübinger, Walter \& Knoll 2017; Sitorus, 2018).

\subsection{Financial Resources and Fund Management}

Mosques received funds or financial support from two particular sources. The first source is in the form of grant from state government or Islamic Council while the other source is in the form of charities from individuals or corporate. Most mosques in Malaysia do have good financial resources especially in its cash flow and assets.

Although some of the mosques in Malaysia were able to collect a huge sum of contributions from individuals and corporates, the management of the fund was still in question. Most of them only used the fund to pay utility bills, invited speakers, and small-scale maintenance of the mosque. The excess were then parked as their savings in any banking institution where some had even reached thousands of ringgit as in bank alone (Mohd Yahya et.al (2014); Azila et.al (2014).

\subsection{Administration Background and Efficiency}

In general, a religious institution were administered by those who have different academic backgrounds and possessed little knowledge on management and accountings (R. Laughlin, 1998) whereas a good structured management and controls are essentials in delivering services for the community (Al-Darwani, 2007; Rahma, 2017). Hence, in order to have a smooth management, mosque institutions require sufficient numbers of skilled workers (Mohamed Azam et.al, 2013). In order for a mosque to be administered effectively, the efficiency of the administrator and its appointed committee members is very essential.

The background of the appointed committee members will play a big part in order for the mosque to be managed properly and all of the planned activities to be well organized. According to Khairil Anwar (1996), appointments of under qualified staff in mosques would bring negative implications on the mosques itself. Mohd Yahya et.al (2014) also found that age and level of education were the factor behind the limitations of a mosque in planning and organizing activities that can benefit the locals although some of the committee members have had joined a course on it before.

\section{Research Methodolgy}

This study utilized qualitative method through observation of the scenario and words from data that were collected, analysed, and interpreted. A semi-structured interview was done on main respondent, which are the mosques' management committee members and the administration. The study used objective sampling technique that is commonly used in a qualitative research. This study was done in Kelantan by choosing several different mosques as sample study. At the early stage of the research, interviews with mosques' committee members were done for five different mosques. However, this research only focused on three mosques since the other two could not provide adequate information and did not meet the research objectives.

Information obtained from the respondents was analysed using Atlas.ti software for its coding and theme. This study utilized a thematic analysis where the result would be based on theme frameworks in order to get the main result out of every theme. In this study, source of fund, distribution of fund, and efficiency were set as the framework in analysing obtained data.

\section{Findings}

\begin{tabular}{clll}
\hline \multicolumn{1}{c}{ Findings } & \multicolumn{1}{c}{ Mosque A } & \multicolumn{1}{c}{ Mosque B } & \multicolumn{1}{c}{ Mosque C } \\
\hline Source of Fund & $\bullet$ Not receive a fix & $\bullet$ The main source of fund & $\bullet$ The main source of \\
& $\begin{array}{l}\text { allocation from both the } \\
\text { Federal Government and }\end{array}$ & $\begin{array}{l}\text { was from donations } \\
\text { through daily and }\end{array}$ & $\begin{array}{l}\text { fund was from the } \\
\text { Friday's collection. }\end{array}$ \\
\hline
\end{tabular}




\begin{tabular}{|c|c|c|c|}
\hline & $\begin{array}{l}\text { State Government } \\
\text { - Generate continuous } \\
\text { income (weekly fund } \\
\text { raising every Friday and } \\
\text { Monday) } \\
\text { - Created fund collected } \\
\text { monthly from charitable } \\
\text { individuals and corporate } \\
\text { sectors } \\
\text {-Income also generated } \\
\text { from business activities } \\
\text { (selling stickers, rental of } \\
\text { massage chair, managing } \\
\text { kiosks) }\end{array}$ & $\begin{array}{l}\text { Friday's collections } \\
\text { - Had built kiosks within } \\
\text { its vicinity. However, the } \\
\text { rentals is collected by } \\
\text { MAIK } \\
\text { - MAIK would only } \\
\text { contribute fund if it } \\
\text { involves a huge amount } \\
\text { of money and based on } \\
\text { the mosque need. } \\
\text { However, this fund was } \\
\text { only limited to certain } \\
\text { specific activities }\end{array}$ & $\begin{array}{l}\text {-Other income from } \\
\text { business activities } \\
\text { (massage chair, selling } \\
\text { mineral water) } \\
\text { - Received annual } \\
\text { allocations from } \\
\text { MAIK. }\end{array}$ \\
\hline Distribution of Fund & $\begin{array}{l}\text { - Distributed and utilized } \\
\text { for organizing activities } \\
\text { such classes, programs } \\
\text { with the local } \\
\text { community, supporting } \\
\text { staff allowances, utilities, } \\
\text { maintenance, and } \\
\text { cleaning services of the } \\
\text { mosque } \\
\text { - Had fund allocated } \\
\text { specifically for the } \\
\text { people in needs }\end{array}$ & $\begin{array}{l}\text { - Organizing an annual } \\
\text { youth carnival } \\
\text { - Distributed the fund by } \\
\text { giving some donations to } \\
\text { the people that were in } \\
\text { need and came to the } \\
\text { mosque for help }\end{array}$ & $\begin{array}{l}\text {-Expenses were made } \\
\text { for guest speakers, } \\
\text { staff allowances, cost } \\
\text { of development, } \\
\text { operation expenses on } \\
\text { Tahfiz program, } \\
\text { utilities, maintenance } \\
\text { and cleaning services } \\
\text { - Had fund allocated } \\
\text { specifically for the } \\
\text { people in needs }\end{array}$ \\
\hline $\begin{array}{l}\text { Efficiency and Background of } \\
\text { Committee Members }\end{array}$ & $\begin{array}{l}\text { - Has } 12 \text { bureaus that are } \\
\text { responsible for planning } \\
\text { and implementing } \\
\text { policies that were agreed } \\
\text { by the mosque's } \\
\text { management } \\
\text { - Has a good hierarchy } \\
\text { structure since the } \\
\text { committee members } \\
\text { appointed were a mix of } \\
\text { professionals and locals. } \\
\text { - The appointed members } \\
\text { would be sent to attend } \\
\text { any suitable courses } \\
\text { - The committee } \\
\text { members of this mosque } \\
\text { actively committed and } \\
\text { involved in many } \\
\text { discussions, planning, } \\
\text { and the implementations } \\
\text { of their agenda. }\end{array}$ & $\begin{array}{l}\text { - The committee } \\
\text { members of this mosque } \\
\text { were made up of various } \\
\text { backgrounds } \\
\text { - The coordination } \\
\text { committee involved local } \\
\text { people without any } \\
\text { allowances given. } \\
\text { - Their experiences in } \\
\text { financial management } \\
\text { and business somewhat } \\
\text { provided a positive } \\
\text { impact on the mosque's } \\
\text { development and } \\
\text { activities }\end{array}$ & $\begin{array}{l}\text { - The management } \\
\text { was made up of Imam } \\
\text { Tua and Imam Muda } \\
\text {-Appointment of the } \\
\text { committee members } \\
\text { was done once every } \\
\text { two years on } \\
\text { voluntary basis and } \\
\text { they are from various } \\
\text { professional } \\
\text { backgrounds with vast } \\
\text { experience. } \\
\text { - No specific financial } \\
\text { courses provided for } \\
\text { the committee } \\
\text { members } \\
\text { - The staff appointed } \\
\text { by MAIK must go } \\
\text { through courses } \\
\text { organized from time } \\
\text { to time to enhance } \\
\text { their skill and } \\
\text { knowledge } \\
\text { mosque's in } \\
\text { administration and } \\
\text { financial management. }\end{array}$ \\
\hline
\end{tabular}




\section{Overall Analysis}

\subsection{Source of Fund}

The sources of fund were through contributions made by the public and the government though it was observed that the contributions made by the public were more dominant. This study found that the mosques' well-organized activities and operations influenced the public to donate and contribute more to the mosques. In general, all of the mosques under study did not receive fund directly from the government or Majlis Agama Islam Kelantan (MAIK). MAIK however did provide funds simply as a contribution for the mosques or based on their needs and request. Besides, MAIK would only pay the salary or allowances of the staff appointed by MAIK.

\subsection{Distribution of Fund}

In general, the utilization of funds was more focused on the utilities and facilities of the mosques. Furthermore, all of the mosques under study were using a lot of modern facilities. Funds obtained were also allocated to organize educational activities at the mosques. Moreover, some business activities done involved rental of spaces for massage chair services, selling of mineral water, guesthouse service, and even kiosks in the mosques' area. A lot of programs held by the mosques prioritized and focused on engaging community including the distribution of fund that was not only focusing on individuals or locals but also involved other mosques in other area.

\subsection{Efficiency and Background of Committee Members}

In general, every mosque under study had formal committee members that were appointed by MAIK or specific appointment by the management of the mosques. Although there was only one mosque under study that sent their committee members to attend certain courses, management of the mosques in general did not provide or send their appointed members to undertake courses to increase their efficiency and administration k now how. Most of the appointed members were experience individuals in their own field either corporate or public sectors as well as businessmen. Their experience and networking provided the mosques an extra advantage in their administration and management especially in terms of ideas given on any particular planned activities.

\section{Conclusion \& Recommendations}

The findings from this study showed that these mosques had a various sources of fund with majority of it came from contributions by the public. The distribution of funds was also done efficiently and was optimally used on activities related to the mosque development and engagement with the community. However, the study found that they are not seriously engaged in income generating activities due to the fact that they would continuously be receiving fund from the public.

Overall, the three mosques studied had a quite similar source and distribution of funds as well as the efficiency and background of their committee members. However, it could be seen that some were more active than the other especially in terms of their income generating programs. It was proven from the study that the involvement of mosques in income generating activities was highly depending not only on efficiency and background of their committee, but also on the effort and commitment of their committee members.

It is undeniable that the three mosques under study were very active in organizing scheduled classes daily and weekly, Subuh and Maghrib and even monthly. However, they are recommended to organize more special classes inviting celebrity guest speakers in order to attract more people to come to the mosque. For this purpose, the mosques can grab the opportunity to collect more funds, as there will be many visitors coming to the mosques for the special event.

\section{References}

Al-Dawarni, A. R. (2007). Falsafah dan Fungsi Masjid Dalam Islam, Masjid Sultan Ismail, Universiti Teknologi Malaysia, Skudai, Johor.

Azila, A. A., Mohd Yahya, M. H., \& Fidlizan, M. (2014). Economic Significance of Mosque Institution in Perak State, Malaysia (Special Feature: Socio-Economic Role of Islamic Finance and its Potential in the Post-Capitalist Era). Kyoto Bulletin of Islamic Area Studies, 7, 98-109.

Fidlizan, M. dan Mohd Yahya, M.H. (2009, Jan-Feb.). Peranan Masjid Sebagai Institusi Sosio Ekonomi bagi Membantu Masyarakat Menghadapi Krisis Ekonomi. Majalah Cahaya, JAKIM.

Jamaliah, S., Azizah M., Zuraidah M.S., \& Sharifah Norzehan, S.Y. (2013). Financial Management Practices in Religious Organizations: An Empirical Evidence of Mosque in Malaysia. International Business Research, 6(7), 111. https://doi.org/10.5539/ibr.v6n7p111 
Joni Tamkin, B., \& Che Zarrina, S. (2003). Pembangunan Ekonomi Masjid dalam Norrodzoh Hj. Siren \& Yusmini Md Yusoff (penyt.), Membangun Institusi Masjid. Kuala Lumpur: Intel Multimedia and Publication.

Joni Tamkin, B., Mohd Yahya, M. H., Fidlizan, M., \& Mohd Fauzi Abu @ Hussin. (2011). Membentuk Usahawan Muslim: Peranan Dana Masjid. Al- Basirah, 1(1), 53-63.

Khairul Anwar, A. (1996). Syarat-Syarat Kelayakan Seorang Imam Masjid Menurut Islam: Kajian Ke Atas Imam di Kawasan Batu Gajah, Perak. (Disertasi Sarjana Usuluddin Bahagian Pengajian Usuluddin, Akademi Pengajian Islam, Universiti Malaya), h. 51.

Laughlin, R. (1988). Accounting in Its Social Context: An Analysis of the Accounting Systems of the Church of England. Accounting, Auditing \& Accountability Journal, 1(2), 19-41. https://doi.org/10.1108/EUM0000000004622

Maliah, S., Siti Alawiah., S., \& Shahul Hameed, M. I. (2008). Internal Control Systems in West Malaysia's State Mosques. American Journal of Islamic Social Sciences, 25(1), 63.

Mohamed Azam, M., Zuraidah, M. S., Noor Azaliah, J., Mohammad Mahyuddin, K., \& Asmah, A. A. (2013). Financial Management Practices of Mosques in Malaysia. GJAT, 3(1), 23-29. https://doi.org/10.7187/GJAT302013.03.01

Mohd Yahya, M. H., Fidlizan, M., Azila, A. R., Nurul Fadly, H. dan Syed Ismail, S.M. (2014). Eksplorasi Dana Kewangan Masjid di Negeri Perak. Prosiding PERKEM VII, Jilid II, 1274-1286.

Promsri, C. (2018). The Influence of External Locus of Control on Life Stress: Evidence from Graduate Students in Thailand. International Journal of Social Sciences Perspectives, 3(1), 38-41. https://doi.org/10.33094/7.2017.2018.31.38.41

Rafindadi, A. A., \& Kondo, K. A. (2018). Public Finance and Rural Development in Nigeria: Empirical Evidence from the Structural Equation Modeling. Asian Economic and Financial Review, 8(11), 1313-1339. https://doi.org/10.18488/journal.aefr.2018.811.1313.1339

Rahma, M. M. (2017). Budget Deficit Sustainability of Bangladesh. Asian Development Policy Review, 5(2), 120-130. https://doi.org/10.18488/journal.107.2017.52.120.130

Shaikh Ali, M. M. (2003). Peranan Masjid Dalam Islam. Yayasan Dakwah Islamiah Malaysia. Universiti Utara Malaysia, Malaysia.

Sitorus, R. R. (2018). Does E-Commerce Effect on Total Tax Paid through Taxpayer's Compliance?. Journal of Accounting, Business and Finance Research, 4(2), 40-48. https://doi.org/10.20448/2002.42.40.48

Stübinger, J., Walter, D., \& Knoll, J. (2017). Financial market predictions with Factorization Machines: Trading the opening hour based on overnight social media data (No. 19/2017). FAU Discussion Papers in Economics.

Zaimeche, S. (2002). Education in Islam: The Role of the Mosque. Manchester: Foundation for Science Technology and Civilisation. 